\title{
Lasiodiplodia pseudotheobromae causes postharvest fruit rot of longan in Thailand
}

\author{
Aimalin Pipattanapuckdee ${ }^{1,2} \cdot$ Danai Boonyakait ${ }^{2,3} \cdot$ Chantalak Tiyayon $^{2,3} \cdot$ Pimjai Seehanam $^{2,3} \cdot$ \\ On-Uma Ruangwong ${ }^{1,2}$
}

Received: 10 January 2019 / Accepted: 1 July 2019 / Published online: 9 July 2019

(C) Australasian Plant Pathology Society Inc. 2019

\begin{abstract}
Fruit rot disease of postharvest longan is a major limiting factor for the longan market in Thailand. The causal fungus was identified as Lasiodiplodia pseudotheobromae based on morphology and analysis of the internal transcribed spacer (ITS) and translation elongation factor 1-alpha (EF1- $\alpha)$ partial genes. This is the first record of L. pseudotheobromae causing fruit rot disease of postharvest longan in Thailand.
\end{abstract}

Keywords Dimocarpus longan · Fruit decay · Identification · Phylogenetic tree · Botryosphaeriaceae

Longan (Dimocarpus longan) is commercially grown in many countries including China, India, Taiwan, Thailand and Vietnam (Jiang et al. 2002). In Thailand, longan growing areas cover about 188,574 ha with total production of $1,027,298 \mathrm{t}$ per year. The major production areas in Thailand are located in the northern region consisting of Chiang Mai, Chiang Rai, Lamphun and Phayao Provinces (Office of Agricultural Economics 2017). Longan fruit is non-climacteric fruit and will not continue to ripen once removed from the tree (Drinnan 2004). Consequently, fruit must be harvested when their skin become yellow-brown and their flesh reaches optimal eating quality. Browning of longan fruits are associated with desiccation, heat stress, senescence, chilling injury and pest or pathogen attack (Pan 1994). The most important fruit rot disease of longan caused by fungi including Lasiodiplodia sp., Pestalotiopsis sp. and Xylaria sp. (Chang-ngern et al.

On-Uma Ruangwong

On-uma.r@cmu.ac.th

Aimalin Pipattanapuckdee

aimalin_p@cmu.ac.th

1 Division of Plant Pathology, Department of Entomology and Plant Pathology, Faculty of Agriculture, Chiang Mai University, Chiang Mai 50200, Thailand

2 Postharvest Technology Innovation Center, Office of the Higher Education Commission, Bangkok 10400, Thailand

3 Division of Horticulture, Department of Plant and Soil Sciences, Faculty of Agriculture, Chiang Mai University, Chiang Mai 50200, Thailand
2010). In this study, we conducted morphological and phylogenetic analyses using ITS and $E F 1-\alpha$ genes to identify the potential causal agent of longan fruit rot disease.

Longan fruit rot symptoms were observed and collected from a longan orchard during August 2018 until October 2018 at Lamphun Province, Thailand. Longan fruits were incubated in a plastic box for observation of symptom development. The fungal pathogen was isolated from the peel of longan fruit by tissue transplanting technique on potato dextrose agar (PDA) (Barnes 1968) and incubated at room temperature for three days. The fungi were re-isolated by hyphal tip isolation and stored on a PDA slant at $4{ }^{\circ} \mathrm{C}$ for further experimentation.

Samples of longan fruit rot were obtained and characterised by observation of the colour of the pericarp. The infected pericarp became brown and developed to a dark-brown and black colour (Fig. 1a). After incubation of longan fruit in a moist chamber, fungal mycelia grew on fruit and formed conidiomata (Fig. 1b). Conidia were released from conidiomata when stored in a moist chamber for three days (Fig. 1c). There were nine fungal pathogens (FRLP1-FRLP9) isolated from infected fruit.

The pathogenicity test of nine isolates were conducted on postharvest longan fruits according to the method of Than et al. (2008) by placing mycelial discs on both wounded (wounded with sterilised needle pricks) and unwounded longan fruits and kept at room temperature. Longan fruits with PDA discs were used as controls. The spore suspension technique was also used to compare. The symptom development was observed at 3,5 and 7 days after inoculation. 
Fig. 1 Fruit rot symptoms on longan; a Longan fruit pericarp browning; b Conidiomata formed on pericarp (arrow); c Conidia released from conidiomata (arrow)
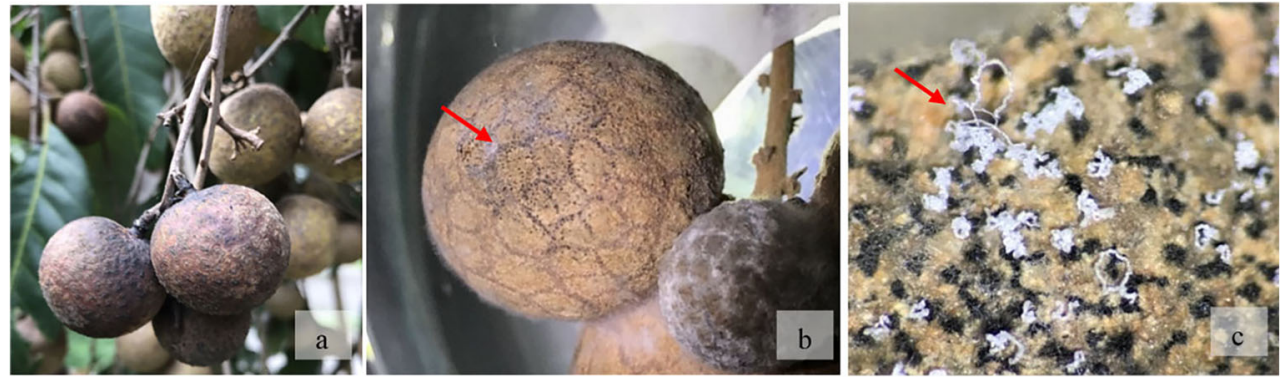

The results showed that at three days after inoculation by mycelial disc and spore suspension, the fungus isolate FRLP1 caused the most severe fruit rot symptoms using both methods. Symptoms on wounded longan fruits, showed the exocarp and endocarp turning dark brown in colour with greyish mycelial growth around the inoculation site, progressing to cover the whole fruit in five days. During the development of the disease, conidia and conidiomata were observed on inoculated fruits while the control showed no symptoms. The isolate FRLP1 was re-isolated from infected longan fruits, fulfilling Koch's postulates.

The fungus was cultured on PDA and incubated at room temperature for observation of colony characteristics. Fungal sporulation was induced by transferring fungal discs onto $2 \%$ water agar (WA) overlaid with sterilised grass leaf (Imperata cylindrica) as a substrate and incubated at room temperature (Suwanakood et al. 2005). Observation and measurement of conidial characteristics were conducted under a compound microscope with a digital camera (Carl Zeiss, Germany).

The colony of the fungus isolate FRLP1 was initially white with woolly aerial mycelia on PDA (Fig. 2a), then became pale grey in colour after 2 weeks of incubation. Conidiomata were produced on $2 \%$ WA overlaid with grass within 10 days (Fig. 2b). Conidiomata were uniloculated, dark brown to black in colour and appeared on the surface of the grass leaf (Fig. 2c). Fungal paraphyses were hyaline, cylindrical shape, aseptate, ends rounded and arising between conidiogenous cells (Fig. 2d). Conidiogenous cells were hyaline, cylindrical, base swollen, holoblastic, proliferating percurrently to form one or two closely spaced annellations. The conidia size was $23.7-28.2 \times 12.4$ $14.9 \mu \mathrm{m}$ and the shape was ellipsoidal with rounded shape at both apex and base. The immature conidia were hyaline and aseptate when released from conidiomata (Fig. 2e). Mature conidia became dark brown with middle one septate and longitudinal striations formed by melanin deposit on inner surface wall of conidia (Fig. 2f). The morphological features of the fungus isolate FRLP1 were similar to other Lasiodiplodia species. However, Lasiodiplodia species could be distinguished by size and shape of conidia and paraphyses (Abdollahzadeh et al. 2010; Alves et al. 2008; Burgess et al. 2006; Coutinho et al. 2017; Dou et al. 2017; Kwon et al. 2017; Linaldeddu et al. 2015;
Fig. 2 Morphological characteristic of the fungus isolate FRLP1; a White and woolly colony and aerial mycelium on PDA; $\mathbf{b}$ Conidiomata on grass (arrow); c Conidiomata formed; $\mathbf{d}$ paraphyses hyaline, cylindrical and aseptate (arrow); e immature conidia hyaline and aseptate; $\mathbf{f}$ mature conidia dark brown colour with one-septate. $\mathrm{Bar}=10 \mu \mathrm{m}$
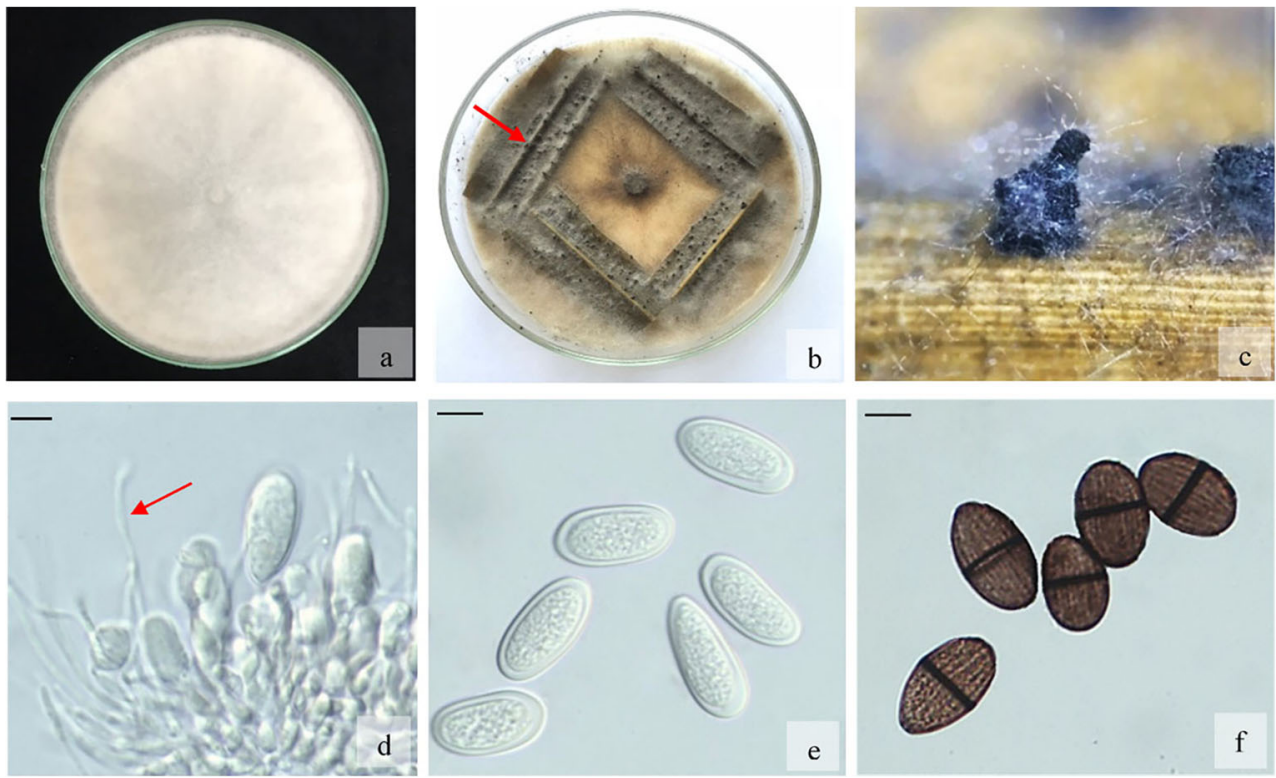
Machado et al. 2014; Munirah et al. 2017; Pavlic et al. 2004; Phillips et al. 2013; Trakunyingcharoen et al. 2015; Yang et al. 2017). For example the conidial size of Lasiodiplodia theobromae was 19.5-27×9.1-15.3 $\mu \mathrm{m}$ with ovoid shape and septate paraphyses compared to L. pseudotheobromae which conidia size were 23.5-32× 12.7-18 $\mu \mathrm{m}$, which were larger than $L$. theobromae, had more ellipsoid and did not taper as strongly towards the base (Table 1).

Moreover, the fungus isolate FRLP1 was confirmed by molecular characterisation using PCR amplification of ITS and EF1- $\alpha$ genes. Genomic DNA was extracted from fungal mycelia according to the method of Myoung et al. (2009). The PCR amplification was performed by EconoTag PLUS GREEN 2X Master Mixed (Lucigen, USA) using ITS gene primers ITS1 (5'TCCGTAGGTGAACCTGCGG-3') and ITS4 (5'TCCTCCGCTTATTGATATGC-3') (White et al. 1990) and the $\mathrm{EF} 1-\alpha$ gene was amplified by using primers EF1-688F (5'-CGGTCACTTGATCTACAAGTGC-3') and EF1-1251R (5'-CCTCGAAC TCACCAGTACCG3') (Cruywagen et al. 2017). The PCR products were analysed by $1.7 \%$ agarose gel electrophoresis stained by RedSafe (iNtRON, South Korea).

Nucleotide sequences were directly analysed using fluorescent dye-terminator sequencing on $\mathrm{ABI}$ Prism $^{\mathrm{TM}}$ 3730xl DNA sequencers (Applied Biosystems, Foster City, CA). All obtained sequences were analysed and aligned using BLAST and MEGA 7 software (Kumar et al. 2016), and then deposited in GenBank. The phylogenetic tree was inferred by using the Maximum Likelihood (ML) method based on the Tamura-Nei model with 1,000 replicates of bootstrap compared to previously reported L. pseudotheobromae, L. theobromae and other members in the family Botryosphaeriaceae (Table 2) which was performed in MEGA 7.

The combined ITS and EF1- $\alpha$ dataset of Lasiodiplodia sp. isolate FRLP1 was deposited in Thailand Bioresource Research Center (TBRC) and deposition number was TBRC10378. The combined dataset containing 1,098 characters (563 from ITS accession MK368390 and 535 from EF1- $\alpha$ accession MK376951) was grouped into L. pseudotheobromae clade and separated from $L$. theobromae clade and other members of the family Botryosphaeriaceae (Fig. 3). The nucleotides of Lasiodiplodia sp. isolate FRLP1 shared $99 \%$ identity to the

Table 1 Morphological characteristics of Lasiodiplodia species

\begin{tabular}{|c|c|c|c|c|}
\hline \multirow[t]{2}{*}{ Species } & \multicolumn{2}{|l|}{ Conidia } & \multirow[t]{2}{*}{ paraphyses } & \multirow[t]{2}{*}{ Source of data } \\
\hline & Conidial size $(\mu \mathrm{m})$ & septation & & \\
\hline \multirow[t]{3}{*}{ L. theobromae } & $26.2-27.0 \times 14.0-14.4$ & 1 & septate & Alves et al. 2008 \\
\hline & $19.7-26.7 \times 10.9-15.3$ & 1 & septate & Coutinho et al. 2017 \\
\hline & $20.0-21.8 \times 9.1-10.9$ & 1 & septate & Munirah et al. 2017 \\
\hline \multirow[t]{4}{*}{ L. pseudotheobromae } & $23.5-32.0 \times 14.0-18.0$ & 1 & aseptate & Alves et al. 2008 \\
\hline & $25.5-27.3 \times 12.7-14.6$ & 1 & aseptate & Munirah et al. 2017 \\
\hline & $24.0-27.0 \times 13.0-16.0$ & 1 & aseptate & Kwon et al. 2017 \\
\hline & $23.7-28.2 \times 12.4-14.9$ & 1 & aseptate & This study \\
\hline L. crassispora & $27.0-33.0 \times 14.0-17.0$ & 1 & septate & Burgess et al. 2006 \\
\hline L. citricola & $20.0-31.0 \times 11.0-19.0$ & 1 & septate & Abdollahzadeh et al. 2010 \\
\hline L. venezuelensis & $26.0-33.0 \times 12.0-15.0$ & 1 & septate & Burgess et al. 2006 \\
\hline L. lignicola & $15.0-17.5 \times 8.0-11.0$ & $\mathrm{UN}^{1}$ & aseptate & Phillips et al. 2013 \\
\hline L. sterculiae & $14.0-16.0 \times 10.0-11.0$ & UN & UN & Yang et al. 2017 \\
\hline L. chinensis & $19.0-25.0 \times 12.0-14.0$ & 1 & septate & Dou et al. 2017 \\
\hline L. mediterranea & $26.3-37.0 \times 13.5-18.0$ & $1-2$ & septate & Linaldeddu et al. 2015 \\
\hline L. vitis & $26.0-28.0 \times 15.0-16.0$ & 1 & aseptate & Yang et al. 2017 \\
\hline L. subglobosa & $16.0-23.0 \times 11.0-17.0$ & 1 & aseptate & Machado et al. 2014 \\
\hline L. macrospora & $28.0-35.0 \times 15.0-17.0$ & $1-3$ & septate & Machado et al. 2014 \\
\hline L. thailandica & $20.0-26.0 \times 12.0-16.0$ & 1 & septate & Trakunyingcharoen et al. 2015 \\
\hline L. parva & $15.5-24.5 \times 10.0-14.5$ & 1 & septate & Alves et al. 2008 \\
\hline L. gonubiensis & $28.0-39.0 \times 14.0-21.0$ & $1-3$ & aseptate & Pavlic et al. 2004 \\
\hline L. parva & $15.5-24.5 \times 10.0-14.5$ & 1 & septate & Alves et al. 2008 \\
\hline
\end{tabular}

Note: ${ }^{1} \mathrm{UN}=$ unknown 
Table 2 Accession code of the sequences used in the phylogenetic analysis

\begin{tabular}{|c|c|c|c|c|c|}
\hline \multirow[t]{2}{*}{ Isolate Number ${ }^{\mathrm{a}}$} & \multirow[t]{2}{*}{ Species } & \multirow[t]{2}{*}{ Location } & \multirow[t]{2}{*}{ Host } & \multicolumn{2}{|l|}{ GenBank $^{\mathrm{b}}$} \\
\hline & & & & ITS & $\mathrm{EF} 1-\alpha$ \\
\hline CGMCC3.18066 & L. chinensis & China & Hevea brasiliensis & KX499899 & KX499937 \\
\hline CGMCC3.18067 & L. chinensis & China & Sterculia lychnophora & KX499901 & KX499939 \\
\hline CBS 124707 & L. citricola & Iran & Citrus sp. & GU945354 & GU945340 \\
\hline IRAN 1521C & L. citricola & Iran & Citrus sp. & GU945353 & GU945339 \\
\hline CBS 118741 & L. crassispora & Australia & Santalum album & DQ103550 & DQ103557 \\
\hline CMW 13488 & L. crassispora & Venezuela & Eucalyptus urophylla & DQ103552 & DQ103559 \\
\hline CBS 115812 & L. gonubiensis & South Africa & Syzygium cordatum & DQ458892 & DQ458877 \\
\hline СРC 22781 & L. gonubiensis & Thailand & Phyllanthus emblica & KM006443 & KM006474 \\
\hline CBS 134112 & L. lignicola & Thailand & Dead wood & JX646797 & KU887003 \\
\hline CMM 3833 & L. macrospora & Brazil & Jatropha curcas & KF234557 & KF226718 \\
\hline CBS 137783 & L. mediterranea & Italy & Quercus ilex & KJ638312 & KJ638331 \\
\hline CBS 137784 & L. mediterranea & Italy & Vitis vinifera & KJ638311 & KJ638330 \\
\hline CBS 456.78 & L. parva & Columbia & Cassava field-soil & EF622083 & EF622063 \\
\hline CBS 356.59 & L. parva & Sri Lanka & Theobroma cacao & EF622082 & EF622062 \\
\hline MHGNUF120 & L. pseudotheobromae & Korea & Mangifera indica & KY404091 & KY404090 \\
\hline CBS 116460 & L. pseudotheobromae & Costa Rica & Gmelina arborea & EF622078 & EF622058 \\
\hline СРC 22756 & L. pseudotheobromae & Thailand & Osmanthus fragrans & KM006434 & KM006465 \\
\hline CPC 22758 & L. pseudotheobromae & Thailand & Hevea brasiliensis & KJ607141 & KJ607151 \\
\hline CPC 22770 & L. pseudotheobromae & Thailand & Persea Americana & KJ607146 & KJ607156 \\
\hline СРC 22777 & L. pseudotheobromae & Thailand & Coffea arabica & KM006439 & KM006470 \\
\hline TBRC10378 & L. pseudotheobromae & Thailand & Dimocapus longan & MK368390 & MK376951 \\
\hline CBS 342.78 & L. sterculiae & Germany & Sterculia oblonga & KX464140 & KX464634 \\
\hline CMM 3872 & L. subglobosa & Brazil & Jatropha curcas & KF234558 & KF226721 \\
\hline СРC 22795 & L. thailandica & Thailand & Mangifera indica & KJ193637 & KJ193681 \\
\hline CGMCC3.18382 & L. thailandica & China & Podocarpus macrophyllus & KY767662 & KY751303 \\
\hline CBS 164.93 & L. theobromae & Papua New Guinea & Fruit along coral reef coast & AY640255 & AY 640258 \\
\hline CBS190.73 & L. theobromae & Tanzania & Persea americana & EF622068 & EF622048 \\
\hline CBS 287.47 & L. theobromae & Unknown & Musa sapientum & EF622069 & EF622049 \\
\hline PHLO9 & L. theobromae & Puerto Rico & Dimocapus longan & KC964546 & KC964552 \\
\hline СРC 22766 & L. theobromae & Thailand & Pinus kesiya & KM006436 & KM006467 \\
\hline CMW 13512 & L. venezuelensis & Venezuela & Acacia mangium & DQ103548 & DQ103569 \\
\hline CBS 118739 & L. venezuelensis & Venezuela & Acacia mangium & DQ103547 & DQ103568 \\
\hline CBS 128313 & L. viticola & USA & Vitis vinifera & HQ288227 & HQ288269 \\
\hline CBS 124060 & L. vitis & Italy & Vitis vinifera & KX464148 & KX464642 \\
\hline CBS 110299 & N. luteum & Portugal & A.J.L. Phillips & AY259091 & AY573217 \\
\hline
\end{tabular}

${ }^{a}$ Abbreviation of isolate and culture collection: CBS - Centraalbureau voor Schimmelcultures, Utrecht, The Netherlands; CMW - M.J. Wingfield, FABI, Universityy of Pretoria, South Africa; CPC - Culture Collection of P.W. Crous, housed at CBS; MHGNU - Department of Plant Medicine Gyeongsang National University, Republic of Korea

${ }^{\mathrm{b}}$ ITS - internal transcribed spacer; EF1- $\alpha$ - encoding translation elongation factor 1-alpha gene

reference L. pseudotheobromae isolate MHGNUF120 (accessions KY404091 and KY404090) (Kwon et al. 2017).

From morphological and phylogenetic analysis, the result showed that the fungal isolate FRLP1 could be identified as $L$. pseudotheobromae, a member of Botryosphaeriaceae, which was commonly found as endophytes and pathogens of various plants in tropical and subtropical regions (Rosado et al. 2016). These fungi are generally regarded as opportunistic pathogens with a latent endophytic stage causing numerous diseases when the host plants are exposed to stress or favorable conditions for disease development (Slippers 


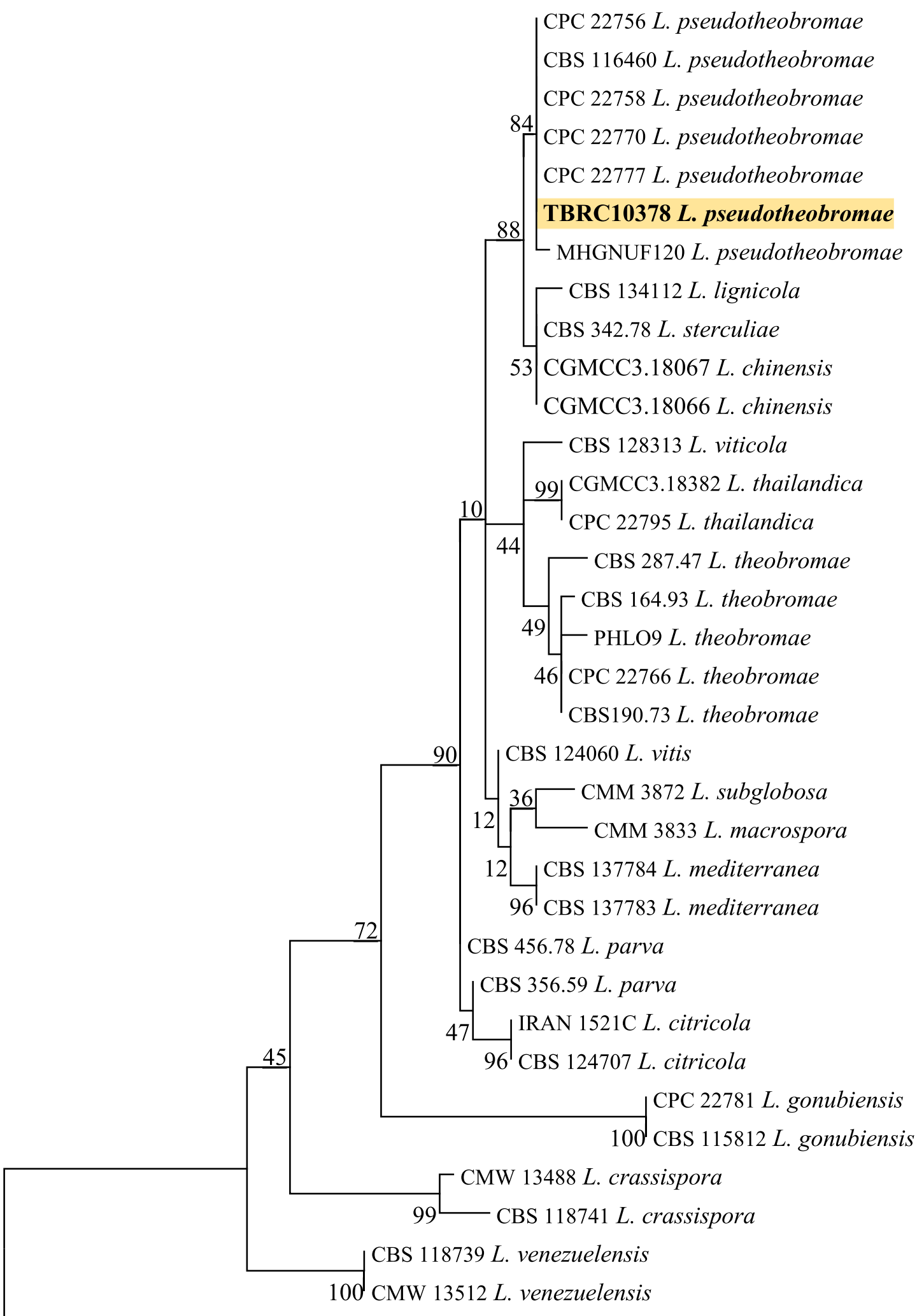

CBS 110299 Neofusicoccum luteum

\section{$\stackrel{\vdash}{ }$}

Fig. 3 The maximum likelihood tree generated from the combine analysis of ITS and EF1- $\alpha$ dataset. Designated out group taxon is
Neofusicoccum luteum. Bootstrap support values from 1,000 replications are shown in the branches 
and Wingfiled 2007). Botryosphaeriaceae were entering the fruit through scars at the stem-end of fruit and fungi colonised and latently remained in the pericarp (Ladanyia 2008). Symptoms of the fruit rot disease cause by $L$. pseudotheobromae, will develop after harvest especially under high temperature and high humidity conditions (Zhang 2014).

Lasiodiplodia pseudotheobromae was reported for the first time on grapevine in Brazil as a grapevine trunk pathogen (Correia et al. 2013) and mostly found in Africa, Europe and Latin America (Adetunji and Oloke 2013). In the case of Thailand, L. pseudotheobromae has been reported to cause canker, decline, dieback, stem end rot, and fruit rot on a wide range of plants (Farungsang et al. 1992; Trakunyingcharoen et al. 2013). L. pseudotheobromae has been identified as a causal agent of inflorescence blight of longan in Puerto Rico (Serrato-Diaz et al. 2014). To our knowledge, this is the first report of $L$. pseudotheobromae causing fruit rot disease of postharvest longan in Thailand.

Acknowledgements This research is supported by the Postharvest Technology Innovation Center, Office of the Higher Education Commission, Bangkok, Thailand.

\section{References}

Abdollahzadeh J, Javadi A, Goltapeh EM, Zare R, Phillips AJL (2010) Phylogeny and morphology of four new species of Lasiodiplodia from Iran. Persoonia 25:1-10

Adetunji CO, Oloke JK (2013) Effect of wild and mutant strain of Lasiodiplodia pseudotheobromae mass product on rice bran as a potential bioherbicide agents for weeds under solid state fermentation. JABB 1:18-23

Alves A, Crous PW, Correia A, Phillips AJL (2008) Morphological and molecular data reveal cryptic speciation in Lasiodiplodia theobromae. Fungal Divers 28:1-13

Barnes EH (1968) Fusarium wilt of tomato isolation and observation. In: Atlas and manual of plant pathology. Plenum press, New York, $p$ 238

Burgess TI, Barber PA, Mohali S, Pegg G, de Beer W, Wingfield MJ (2006) Three new Lasiodiplodia spp. from the tropic, recognized based on DNA sequence comparisons and morphology. Mycologia 98:423-435

Chang-ngern P, Sardsud U, Pathomaree W, Chantrasri P, Chukeatirote E (2010) Diversity of molds in fresh longan. Agric Sci J 41(1):322324

Correia KC, Camara MPS, Barbosa MAG, Sales R Jr, Augusti-Brisach C, Gramaje D, Leon M, Garcia-Jimenez J, Abad-Campos P, Armengol J, Michereff SJ (2013) Fungal trunk pathogens associated with table grape decline in northeastern Brazil. Phytopathol Mediterr 52:380387

Coutinho IBL, Freire FCO, Lima CS, Lima JS, Goncalves FJT, Machado AR, Silva AMS, Cardoso JE (2017) Diversity of genus Lasiodiplodia associated with perennial tropical fruit plants in northeastern Brazil. Plant Pathol 66:90-104

Cruywagen EM, Slippers B, Roux J, Wingfield MJ (2017) Phylogenetic species recognition and hybridization in Lasiodiplodia: a case study on species from baobabs. Fungal biol 121:420-436

Dou ZP, He W, Zhang Y (2017) Lasiodiplodia chinensis sp. nov., a new holomorphic species from China. Mycosphere 8(2):521-532
Drinnan J (2004) Longan postharvest handling and storage. A report for the Rural Industries Research and Development Corporation. $18 \mathrm{p}$

Farungsang U, Sangchote S, Farungsang N (1992) Appearance of quiescent fruit rot fungi on rambutan stored at $13{ }^{\circ} \mathrm{C}$ and $25^{\circ} \mathrm{C}$. Acta Horti (321):903-907

Jiang Y, Zhang Z, Joyce DC, Ketsa S (2002) Postharvest biology and handling of longan fruit (Dimicarpus longan Lour.). Postharvest Biol Technol 26:241-252

Kumar S, Stecher G, Tamura K (2016) MEGA7: molecular evolutionary genetics analysis version 7.0 for bigger datasets. Mol Biol Evol 33: 1870-1874

Kwon JH, Choi O, Kang B, Lee Y, Park J, Kang DW, Han I, Kim J (2017) Identification of Lasiodiplodia pseudotheobromae causing mango dieback in Korea. Can J Plant Pathol 39(2):241-245. https://doi.org/ 10.1080/07060661.2017.1329231

Ladanyia M (2008) In: Ladaniya M (ed) Postharvest disease and their management. Citrus Fruit. Academic Press, USA, pp 417-444

Linaldeddu BT, Deidda A, Scanu B, Franceschini A, Serra S, BerrafTebbal A, Zouaoui M, MLB J, Phillips AJL (2015) Diversity of Botryospaeriaceae species associated with grapevine and other woody hosts in Italy, Algeria and Tunisia, with descriptions of Lasiodiplodia exigua and Lasiodiplodia mediterranea sp. nov. Fungal Diver 71:201-204

Machado AR, Pinho DB, Pereira OL (2014) Phylogeny, identification and pathogenicity of the Botryosphaeriaceae associated with collar and root rot of the biofuel plant Jatropha curcas in Brazil, with a description of new species of Lasiodiplodia. Fungal Divers 67:127141

Munirah MS, Azmi AR, Yong SYC, Nur AIMZ (2017) Characterization of Lasiodiplodia theobromae and L. pseudotheobromae causing fruit rot on pre-harvest mango in Malaysia. Plant Pathol Quar 7(2): 202-213

Myoung HC, Sook YP, Yong HL (2009) A quick and safe method for fungal DNA extraction. Plant Pathol J 25(1):108-111

Office of Agricultural Economics (2017) Agricultural Statistics of Thailand 2017. Ministry of agriculture and cooperatives. The agricultural co-operative Federation of Thailand, limited Publisher, branch no. 4. Nonthaburi:174

Pan XC (1994) Study on relationship between preservation and microstructure of euphoria Longan fruit. J Guangxi Agric Univ 13:185188

Pavlic D, Slipper B, Coutinho TA, Gryzenhout M, Wingfield MJ (2004) Lasiodiplodia gonubiensis sp. nov., a new Botryosphaeria anamorph from native Syzygium cordium in South Africa. Stud Mycol 50:313322

Phillips AJL, Alves A, Abdollahzadeh J, Slipper B, Wingfield MJ, Groenewald JZ, Crous PW (2013) The Botryospheriaceae: genera and species known from culture. Stud Mycol 76:51-167

Rosado AWC, Machado AR, Freire FCO, Pereira OL (2016) Phylogeny, identification, and pathogenicity of Lasiodiplodia associated with postharvest stem-end rot of coconut in Brazil. Plant Dis 100:561568

Serrato-Diaz LM, Vergas LIR, Goenaga R, French-Monar R (2014) First report of Lasiodiplodia theobromae causing inflorescence blight and fruit rot of Longan (Dimocarpus longan L.) in Puerto Rico. Plant Dis 98(2):279

Slippers B, Wingfiled MJ (2007) Botryosphaeriaceae as endophytes and latent pathogens of woody plants: diversity, ecology and impact. Fungal Biol Rev 21:90-106

Suwanakood P, Sardsud V, Sangchote S, Sardsud U (2005) Microscopic observation and pathogenicity determination of common molds on postharvest Longan fruit cv. Daw Asian J Biol Educ 3:47-53

Than PP, Jeewon R, Hyde KD, Pongsupasamit S, Mongkolporn O, Taylor PWJ (2008) Characterization and pathogenicity of Colletotrichum species associated with anthracnose on chili (Capsicum spp.) in Thailand. Plant Pathol 57:562-572 
Trakunyingcharoen T, Cheewangkoon R, To-anun C (2013) Phylogeny and pathogenicity of fungal species in the family Botryosphaeriaceae associated with mango (Mangifera indica) in Thailand. Int J Agric Technol 9(6):1535-1543

Trakunyingcharoen T, Lombard L, Groenewald JZ, Cheewangkoon R, To-anun C, Crous PW (2015) Caulicolous Botryospheriales from Thailand. Persoonia 34:87-99

White TJ, Bruns T, Lee S, Tayler J (1990) Amplification and direct sequencing of fungal ribosomal RNA genes for phylogenies. In: Innis
AM, Gelfelfard DH, Snindky JJ, White TJ (eds) PCR protocols: a guide to methods and applications. Academic Press, San Diego, pp 315-322

Yang T, Groenewald JZ, Cheewangkoon R, Jami F, Abdollahzadeh J, Lombard L, Crous PW (2017) Families, genera and species of Botryosphaeriales. Fungal Biol 121:322-346

Zhang J (2014) Lasiodiplodia theobromae in citrus fruit (Diplodia stemrot). In: Bautista-Baños S postharvest decay. Academic Press, USA, pp 309-335 